\title{
The research on the difficulties and Countermeasures of college students venture financing route choice
}

\author{
(PRESENTED) \\ XU Xiaojing \\ Chongqing Technology and Business University \\ Chongqing China \\ 34144333@qq.com
}

\begin{abstract}
Entrepreneurship of college students is becoming more and more in the entrepreneurial process, insufficient funds is a big problem in the business. The rapid development of the current domestic financing path are diversified, and college students' venture financing path is very narrow. This paper analyzes the college students' plight of entrepreneurs on the financing channels to choose and reasons, and the different financing channels should be how to improve the success rate of financing put forward countermeasures and Suggestions.
\end{abstract}

Keywords - Entrepreneurship of college students; financing route; Countermeasures;

\section{INTRODUCTION}

Venture financing is a necessary problem for entrepreneurs to face. The problem that it is difficult for entrepreneurs to raise funds especially for college entrepreneurs. Nowadays Chinese government advocates public business. College students respond positively to the call of the times and the ratio of college students' business increased year by year. But the chance of success for college students' business is not high. The 2014 College Students Employment Blue Book released by My COS Institute pointed out that the proportion of college students' venture business who graduated from college over half a year was increasing from 2011 to 2013 to a point of 2.3\%. While the 2012 College Students Employment Blue Book showed that the ratio of college students' creating business was reached 20 to 23 percent in USA[1].As to the success rate for college students in China, there is not beyond 10 percent[2]. The highest success rate in China is in Zhejiang province only 4 percent which is much lower than the average rate 20 percent around the world. Among them, 68.12 percent of college students failed in venturing business due to lack of money[1]. According to My COS survey, money that college students start their own business mainly relies on self-funding channels, such as their parents and individual saving. Among graduates in 2011 session, 80 percent college students create their own business through this channel [3]. By comparison, the proportion of financing from other sources is very low. From the above analysis and comparison, it is concluded that financing problem has become a huge obstacle for college students' venturing. So how should college students raise fund effectively? To find the right path to raise money is the key to solve the financing problem of venture.
In the existing literature of problems for students raise money, there is few research literature especially for financing path. The existing research paper regards the narrow path for financing as the reasons for difficulty in raising fund. The existing suggestions to solve the problem of financing are mainly from the aspect of government and financial institutes among which few of them trying to analyze reasons and put forward countermeasures are from the aspect of college student as entrepreneurs. This paper aims to help students understand the obstacles for financing path correctly and to give recommendations on improving financing efficiency. It is hoped that this paper will provide some reference in solving the financing problem for those college students' entrepreneurs.

\section{The DilemMA For COllege StUdents CHOICE ON VENTURE FINANCING PATH}

There are two ways of financing path for students' entrepreneurs. One is the internal financing whose financing are mainly from their own funds, including the entrepreneurs' (or the partners' or the shareholders') own funds as well as borrowed money from relatives and friends. The other way is external financing in which an enterprise raises funds through a certain way from the other economic agents outside the enterprise. This financing path includes bank loans, private capital and so on. The current situation of college students venture financing path is narrow and low financing rate.

\section{A. Financing path is narrow}

Researchers such as Dai Yiyi and Gu Xiaoyan have investigated the main channels to capital financing among part of college students in Shanghai. The survey data show the main source of venture funding for college students at their beginning stage is self-financing by making use of their own relations, including relatives, students and friends. The future start-up funding for entrepreneurs who are interested in starting business in the future is that 41.66 percent mainly comes from self-financing, 22.92 percent from bank loan, 10.42 percent from venture investment and 25 percent from venture capital fund. The ratio of self-funding reaches as high as 77.78 percent for those who are starting their business. Among the rest part, 3.7 percent comes from petty loan, 11.11 percent from venture investment and 7.41 percent from venture capital fund[1]. Researchers as Liu Yaqi and Guo 
Haoguo have carefully analyzed the problems of investment and financing among college students from six universities in Changsha, Hunan province. It is fund that the main ways for college students to raise money are self-funding, bank loan and equity financing. The main channels for them to raise fund are from families and friends[4]. Researchers as Aoshan have also analyzed the problems of investment and financing among college students in Beijing. It is fund that 48 percent entrepreneurs get money through partnership and 22 percent is individual investment. While, only 6 percent of entrepreneurs start their business by venture investment[5].

From the above analysis, the main channel for college students finnacing is self-funding. However, this is the same of other cities. Such results from survey demonstrate the situation that the path for college students to raise money is poor.

\section{B. Low financing rate}

The amount of self-financing is very limited which can not meet the subsequent requirements for financing to initiate the project and stimulate business growth. College students can turn to bank loans, angel investment, risk investment and financing so as to realize the needs of funding for business start-ups. However, the reality is that commercial banks for loan review are very strict requiring guarantee and collateral. For the entrepreneurial college students, it is difficult to get the loans they need. In recent years, venture investment is more and more widely welcomed by college students as their top choice for financing. But in order to get the favor of venture investors, entrepreneurs have to make full preparation such as to formulate a perfect, viable and attractive business plan so as that it is likely to get the investment. At the same time, it is easy for venture investors to conflict with entrepreneurs on the controlling rights. Audit on individual debt from the banks is very strict. For entrepreneurial college students with relatively no ability to repay the loan, it is hard for them to obtain their desired loan.

\section{REASONS FOR THE DILEMMA OF COLLEGE STUDENT FINANCING PATH}

\section{A. Different stages have different financing channels}

The above referenced survey data demonstrate that selfraised funding is still the main channel for college students' entrepreneurs to raise fund, while, the proportion of other financing channels remains low. But one problem was ignored in these surveys, that is-based on different financing demand, entrepreneurs should choose different financing channels in different stages. Entrepreneurship can be divided into four stages-the entrepreneurial preparation stage, the start-up stage, the business operational stage and the growing stage.

Picture1. Entrepreneurship at Different Stages to the Financing Path

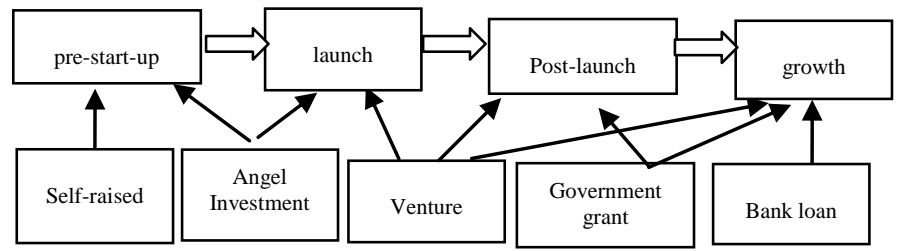

Self-raised funds are generally the main financing channel in entrepreneurship seed and preparation period during which entrepreneurs have a full picture of all information and they do not need too much money, but entrepreneurship expected return contains many uncertainties. The main characters of angel investment which is usually adopted during the initial and the start-up stages are that entrepreneurs have made the business planning book and feasibility study report through their full market research and repeated verification of entrepreneurial ideas. The risk investment focusing on profit and enterprise management level is usually adopted during the start-up stage and the growing stage. Bank loans or folk small loans focus much on the information symmetry and risk control.

\section{B. Internal Factors}

\section{1) Lack of entrepreneurial ability}

Entrepreneurship can be divided into four stages including business philosophy, market research and validation of business philosophy, setting project management pattern. The first three stages require entrepreneurs have a certain ability of innovation, entrepreneurship and the financing ability. After the project begins, the capability of risk management is demanded. On the other hand, there are some disadvantages for college students' entrepreneurial project, such as low knowledge structure and risk management ability. Thus, it can not reach the requirement of angel investment and venture investment. On the other hand, many college students' entrepreneurs, due to their eager to start the pioneering project or inadequate preparation of entrepreneurship, would encounter the problem of pressing financing which lead to irrational financing options affecting the subsequent financing of the enterprise, such as to give a little money to make big shares, or to sell their own technology at cheap price. This may affect subsequent financing.

\section{2) Lack of Credit Financing}

Under the background of uncompleted social credit system, it is difficult for college students' entrepreneurs to obtain the recognition of social investors. First of all, the management level of college students' entrepreneurs is not high. The capital flow is outside the financial system. There is no sound financial statement and the consciousness for disclosure of information is poor. These factors result in information asymmetry between the entrepreneur and the investor. Thus, the bank can not query the operations of the venture and the entrepreneurs' credit record.

\section{3) Lack of Social Resources}

During their school-days, in addition to parents and relatives, college students have more chance and time to contact with their classmates and peers whose social resources are very limited. In our country, the employment problems of college students are not only college students' own business. By the influence of traditional ideas in China and the existing malpractice under the influence of the education system, the employment of college students is also something on which should parents care about. Under the background of college students' increasing employment pressure, entrepreneurship becomes a helpless choice for some college students because they cannot find a job. Therefore, when college students are lack of money in their business, the family financing has become the first choice for them. The advantage of family financing is that it is fast, and costs is low.

\section{External Factors}

\section{1) The limitation of social financing path}

On the one hand, under the current financial system in our country, the commercial bank is still the main part of money supply. As a result of the high financing threshold among commercial banks which require the borrower to provide collateral or guarantee from Guarantee Company, it is very difficult for college students to get desired money. On the other hand, the Internet financing has been developing rapidly in our country in recent years, but it is still in its 
infancy. The Internet financial company goes bankruptcy from time to time. Common Internet banking and financing paths are $\mathrm{P} 2 \mathrm{P}$, big data and public chips.P2P usually requires the issuer to provide collateral or guarantee. Big data represented by Alabama's microfinance model requires entrepreneurs to start business on Alabama's e-commerce platform. Crowd-funding is the use of the Internet to get individual s' money together so as to provide such finance to entrepreneurs. Because at present China does not allow public chips or the return of funds, so in order to avoid suspicious of illegal fund-raising, the model that individual investors buy a certain product or service in advance to raise money is more like a purchase of a product or service[6].

\section{2) Insufficient policy support from the government}

In recent years, preferential policies and appropriate funds are introduced to support entrepreneurial students ranging from the state council to local government. For example in Shanghai, college students' entrepreneurs can enjoy free risk assessment, the policy of free training, free loan guarantee and other favorable policies such as tax breaks. But for graduates each year, those who choose to embark on the road of entrepreneurship are still few. But the gap between the scale of government's financial support such as venture fund and the actual demand is large. The financing amount is relatively small which is not enough to complete the operation of venture enterprise.

\section{StRATEGY FOR OPtIMIZING FINANCING SUCCESS RATE}

For college students' entrepreneurs, whether they can raise funds quickly and effectively is vital to their entrepreneurial success. In the rapid development of China's financial market, enterprises can get finance from numerous channels. In the face of different financing path, how to improve college students entrepreneurs financing success rate? Start-up financing success rate is related to social capital supply situation, their profit level and development strategy, through different means to select a specific financing way to raise money and the ability to use money.

\section{A. Enhance guidance for start-up financing}

To solve college students' venture financing difficulties, schools and government should act as the main director for college students' entrepreneurs. The current government's guidance is limited to the formulation of the related policies, but the effect of carrying out the policy and effective force is confined. Although many colleges and universities also respond actively to open entrepreneurship courses, much emphasis are put to simple theoretical knowledge which lacks of training classes. But that is far from enough. Canada has more than 200 colleges and universities for students amounted to 830 above the door of entrepreneurship courses[7].

\section{B. Promote the success rate of endogenous financing}

The venture capital for college students' entrepreneurs is of small amount. 60 percent of them needs no more than $100,000 y u a n$. Self-funding is still the main path to raise money for college students' entrepreneurs in our country. Many scholars believe this situation is not reasonable and this is a major obstacle for college student's entrepreneurs. However, in the start-up stage, the information between entrepreneurs and investors is asymmetry. This paper argues that under the background that college students' entrepreneurs lack of social financing resources, self-funding is their top choice. According to Mayer's "Pecking Financial Order Theory", the information constraints of numerous financing channels and the signal passed to investors are different which have different influence on financing costs and the market value. Enterprise's financing decision is based on the principle of minimal cost to choose different financing ways. The first choice is endogenous financing with no transaction costs, followed by debt financing with low transaction costs. The equity financing which is characterized by strict information constraint and may lead to undervalue the enterprise is the last choice for college students' entrepreneurs[8]. Moreover If entrepreneurs need to get loan from commercial banks in subsequent financing, at least 30 percent of their own money is demanded. Thus, it is rational that the main financing path for college students' entrepreneurs is self-funding. This is a fast way to raise funds with low risk and cost.

Although self-raised fund may satisfy the capital needs to a certain degree at the start-up, the success rate of college students' entrepreneurs is extremely low. Therefore, this article suggests that college students find jobs first and then start their business to accumulate both social experience and venture capital for entrepreneurship. Meanwhile it is suggested that college students' entrepreneurs establish legal debt with relatives and friends, namely the legitimate loan contract. In this way, it can protect the interests of the creditors and make the entrepreneurs define the legal liability so as to use money reasonably and carefully.

\section{Promote the success rate of exogenous financing}

\section{1) To promote ability of indirect financing.}

Indirect financing is the most typical way to get loans from commercial banks which requires borrowers to provide collateral or guarantee. Some commercial banks have set up enterprise financing market for small and medium enterprises and developed some financing products for micro-enterprises. Some of these financial products do not need the money raisers to provide collateral or guarantee, such as e-debt and e-browser helper launched by the China Construction Bank. But these products require money raisers to make transactions on the bank's electronic trading platform. For the same reason as credit card, the bank will judge the money raisers' credit according to his transaction records. The more frequent the transaction record is and to make one's repayment on time, better credit record there is. Thus, there's greater chance to obtain money from the bank. So in order to start business by indirect financing, college students entrepreneurs have to establish a good credit record and through the bank system to gradually improve the credit accumulation level to raise funds. And they should improve the financial management ability of the venture project, preparing the complete accounting report.

\section{2) To promote the success rate of direct financing.}

a) The practical experience from developed countries in Europe and America proves that the angel investment which is an important source of equity capital at start-up can deal with the difficulty of enterprises' financing problems effectively. It is a significant booster for the development of enterprises. The enterprises that angel investment invests are those in seed stage and start-up stage. It is usually a one time investment and it is the main financing path for start-ups. Venture investment often goes to invest those enterprises in their development and expansion period. Typically those projects with high technology and innovative business model will attract the attention of the angel investment. College students' entrepreneurs can find risk investment consultation. After failure of getting angel investment, timely and rational assessment and improvement on the project itself are invited. 
In a word, whether it is angel investment, venture investment or other Private capital, they demand high profitability and risk management capability for any entrepreneurs.There are some tips for college students' entrepreneurs to follow in order to obtain funds from investors. First, to promote his entrepreneurship and management skills and to make a perfect entrepreneurial plan book; besides, to let the investors know the start-ups and make it attractive for investors; what's more, if you have already won the investors' trust, in the financing link of angel round or A round, please do not pay much attention to valuations but focus on the amount of money that the project actually needs.

b) With the innovation of financial instruments, college students' entrepreneurs can also get money from the Internet financing platform represented by Alibaba micro-financing model which is based on big data. This model is especially to provide minimal debt service for micro-enterprises[9]. Loan companies will monitor the business behavior, cash flow and other financial and trade situation of micro-enterprises through the e-commerce platform. It will converse the data of micro enterprises' behavior on the e-commerce network into credit evaluation so as to control the risk of debt. In addition, represented by Suning Crowdfunding raise the suggests mode, college students entrepreneurs through the raised platform to booking business products, through product pre-sale financing[10].

\section{CONCLUSIONS AND RECOMMENDATION}

In the rapid development of China's financial market, entrepreneurs have many channels to get funds, but college students still face some problems, such as financing difficulty and narrow financing channels during their entrepreneurship. To solve the financing difficulties for college students' entrepreneurs is to improve the success rate of college students' entrepreneurship so as to improve the employment rate among college students and to boost the economic growth in China.

From the perspective of college students' entrepreneurs, to get more financing channels, they have to first improve their ability of entrepreneurship, enterprise management level and credit level. What's more, during the preparation process of entrepreneurship, they have to gradually expand their social scope to gain more social resources, such as joining in all kinds of business associations or clubs.

From the perspective of government, it will not only give college students some guidance and tax breaks from the microscopes, but also help improve college students' venture financing system. First, the government can provide college students sharing information platform, such as establishing college students' entrepreneurial association, organizations, entrepreneurship competition for college students, or setting up college students' entrepreneurial guidance website, etc Second, The government help set up a project evaluation platform for college students so as to reduce the financing obstacles of information asymmetry. Third, the government will accelerate the development of network public raise, opening all the debt raise and equity raise in particular, in order to provide more new financing paths for college students.
From the perspective of colleges and universities, the entrepreneurship education in school should provide more detailed guidance according to the different stages of entrepreneurship, such as the cultivation of entrepreneurship, business plan writing, business financing and integrity education. Apart from theoretical guidance, colleges should provide college students' entrepreneurs some platforms to practice themselves in order to give them greater chance to gain much experience and to accumulate funds.

\section{NEXT STEPS}

Although the financing path is very extensive, for college students, the practical choice is very limited. Many factors influence the channel and success rate of college students venture financing. For example, the development of venture enterprise financing needs of different stages of evaluation, different financing channels of financing risk and cost comparison, starts an undertaking the enterprise financing ability, investors on the future of the enterprise decisionmaking influence factors. In the face of complex factors, how should college students make the right financing decisions? This needs to establish the financing choice model, and evaluate the influence of different financing route choice of venture enterprise in different stages of development on the value of the entrepreneur.

\section{REFERENCES}

[1] Daiyiyi, guxiaoyan ,Liluhui, Shiyixing , "Shanghai college students' Entrepreneurship Research Report under the constraint of financing”, J, China Market, 2014, 12, pp. 8183

[2] Chenji, "The success rate of college students is less than $10 \%$ ",N,New Citizen Evening News,2014-12-20

[3] Wangjianye, "The research on the application of angel investment in venture financing for College Students,'J, Friend of Accounting,2013.1,pp.109-110

[4] Liuyanqi,Guoyuanhao,Liuyeqing,Lihaohong, "The alysis of the investment and financing problem of college students venture capital in Changsha, ,J, Economic Research Guide,2014.5,pp.192-192

[5] Aoshan, "Investigation and analysis of College Students' Entrepreneurship and venture capital ,"J, China Higher Education Research, 2011.11, PP.21-25

[6] Hushufen,"Innovation of university students venture financing mechanism," J, Management and Administration,2014.12,pp.149-152

[7] Menzies, T. V. Entrepreneurship and the Canadian Universities. Saint Catharines: Brock University,2010.97

[8] Guoweiwei, 'University students' innovative undertaking financing pattern reseach,"M, Shanxi University of Finance and economics,2010.3,pp.9-10

[9] Xujie, Kuibinxian, Jiexiaowen, "Research on Model Innovation of Internet Finance and Small Micro Enterprises Financing,"J, Journal of Business Economics,2014.4,pp.94

[10] Xujie, Kuibinxian, Jiexiaowen, "Research on Model Innovation of Internet Finance and Small Micro Enterprises Financing,”J, Journal of Business Economics,2014.4,pp.95

[11] Yanwensheng, "Research on the Mechanism of start-up financing,"D, WuhanUniversityofTeehnology,2004.11.

[12] Liaoweiwen, "Canadian Small and medium enterprise entrepreneurship service system and Its Enlightenment to China,'J, Enterprise Accounting,2007.4,pp.64-65

[13]EntrePreneurshiPEducationatUniversitiesaBenchmarl'Study,NationalAg encyforEnterpriseandConstruction, 2004

[14][USA]Richard L.Smith,Janet Kiholm Smith,Gaojian translate,Enterpreneurial Finance,2nd edition, $[\mathrm{M}]$,China Machine Press, 2011 